\begin{tabular}{|l|l|l||}
\hline \multicolumn{2}{|c|}{ PublisherInfo } \\
\hline \hline PublisherName & $:$ & BioMed Central \\
\hline \hline PublisherLocation & $:$ & London \\
\hline \hline PublisherImprintName & $:$ & BioMed Central \\
\hline \hline
\end{tabular}

\title{
Recognizing Mom's scent
}

\begin{tabular}{|l|l|l||}
\hline \multicolumn{2}{|c|}{ ArticleInfo } \\
\hline \hline ArticleID & $:$ & 3767 \\
\hline \hline ArticleDOI & $:$ & $10.1186 /$ gb-spotlight-20000915-02 \\
\hline \hline ArticleCitationID & $:$ & spotlight-20000915-02 \\
\hline \hline ArticleSequenceNumber & $:$ & 204 \\
\hline \hline ArticleCategory & $:$ & Research news \\
\hline \hline ArticleFirstPage & $:$ & 1 \\
\hline \hline ArticleLastPage & $:$ & 2 \\
\hline \hline & & RegistrationDate : 2000-09-15 \\
ArticleHistory & $:$ & OnlineDate \\
\hline \hline ArticleCopyright & $:$ & BioMed Central Ltd2000-09-15 \\
\hline \hline ArticleGrants & $:$ & \\
\hline \hline ArticleContext & $:$ & 130591111 \\
\hline \hline
\end{tabular}




\section{William Wells}

Email: wells@biotext.com

Proteins of the major histocompatibility complex (MHC) are involved in cell-cell recognition: they bind and present antigens in the immune system. But, at least in mice, they are also involved in odorbased recognition between individuals. Mice tend to mate with MHC-dissimilar mice (to maintain MHC diversity) and nest with MHC-similar mice. In the September 12 Proceedings of the National Academy of Sciences Yamazaki et al. report that mothers recognize and preferentially retrieve MHC-similar pups, and that pups placed in a maze head for bedding soaked in the urine from an MHC-similar adult mouse (Proc Natl Acad Sci USA 2000, 97:10500-10502). The latter effect is partially, but not completely reversed by foster parenting, suggesting that some part of the response may be learned prenatally or by self-referral.

\section{References}

1. Population biology of antigen presentation by MHC class I molecules.

2. Mating patterns in seminatural populations of mice influenced by MHC genotype.

3. Communal nesting patterns in mice implicate $\mathrm{MHC}$ genes in kin recognition.

4. Proceedings of the National Academy of Sciences, [http://www.pnas.org/] 